\title{
A bibliometric analysis of the application of procalcitonin in patients in the intensive care unit
}

\author{
Yun Tan ${ }^{1 \#}$, Qingtan Yu ${ }^{2 \#}$, Lanxiang Ma ${ }^{3}$, Jiang Chang ${ }^{4}$, Xiujun Zhan ${ }^{5}$, Haibin Cui ${ }^{6}$, Ying Liu ${ }^{7}$, Yongjie Sui ${ }^{8}$ \\ ${ }^{1}$ Laboratory and Pathology, Shaanxi Corps Hospital of Chinese People's Armed Police Forces, Xi'an, China; ${ }^{2}$ Department of Laboratory, Qingdao \\ Special Servicemen Recuperation Center of PLA Navy, Qingdao, China; ${ }^{3}$ Second Department of Characteristic Medicine, Shaanxi Corps Hospital \\ of Chinese People's Armed Police Forces, Xi'an, China; ${ }^{4}$ Department of Anesthesiology, Shaanxi Corps Hospital of Changjiang Armed Police \\ Force, Xi'an, China; ${ }^{5}$ Department of Laboratory of Jiamusi Hospital of Traditional Chinese Medicine, Jiamusi, China; ${ }^{6}$ Health Service, Shaanxi \\ Corps Hospital of Chinese People's Armed Police Forces, Xi'an, China; ${ }^{7}$ First Department of Internal Medicine, Shaanxi Corps Hospital of Chinese \\ People's Armed Police Forces, Xi'an, China; ${ }^{8}$ Outpatient Health Examination Center, Shaanxi Provincial People's Hospital, Xi'an, China \\ Contributions: (I) Conception and design: Y Tan, Y Sui, L Ma; (II) Administrative support: Q Yu, J Chang, X Zhan; (III) Provision of study materials \\ or patients: H Cui, L Ma, X Zhan; (IV) Collection and assembly of data: Y Tan, Q Yu, H Cui, Y Liu; (V) Data analysis and interpretation: Y Tan, \\ Y Sui, H Cui, Y Liu; (VI) Manuscript writing: All authors; (VII) Final approval of manuscript: All authors. \\ "These authors contributed equally to this work and should be considered as co-first authors. \\ Correspondence to: Yongjie Sui. Outpatient Health Examination Center, Shaanxi Provincial People's Hospital, Xi'an 710068, China. \\ Email: mztjzx2250@163.com.
}

Background: Patients in the intensive care unit (ICU) often have serious infections, and anti-infection treatment is vital for these patients. Procalcitonin (PCT) is often used to identify bacterial infections and monitor the effectiveness of anti-infection treatments. This study aims to analyze the current research hotspots of the application of PCT in ICU patients, and to suggest future research directions.

Methods: The Science Citation Index Expanded (SCI-EXPANDED) database in the Web of Science Core Collection (WOSCC) was used as the data source to search literature from 1995 to February 6, 2021. The search strategy was subject term = procalcitonin AND Web of Science categories = Critical Care Medicine. Using CiteSpace software, literature on the application of PCT in ICU patients was analyzed.

Results: A total of 1,243 papers, including 665 (53.5\%) original articles, 87 (7.0\%) reviews, 93 (7.5\%) letters, 297 (23.9\%) conference abstracts, and 101 (8.1\%) other articles, were analyzed. The citation frequency was 40,442, the h-index was 96 , and the average number of citations per item was 32.54. Research was mainly from the United States, Germany, France, and Spain, amongst others. The research institutions were mainly Univ Basel Hosp, Univ Pittsburgh, and Univ Hosp Geneva. Authors including Schuetz P made more contributions. Critical Care Medicine, Intensive Care Medicine, and Critical Care were important journals in this field of research. The keywords with the highest frequency were PCT, sepsis, and infection, and the more central ones were PCT, inflammation, septic shock, and C-reactive protein. The keywords with the strongest citation bursts were PCT, cytokine, and serum.

Conclusions: Papers are mainly published in critical care medical journals. The countries, institutions, and authors that carry out research are relatively limited. The current hot spots are still inflammation, infection, and shock, especially the management and prognosis prediction of critically ill patients.

Keywords! Procalcitonin (PCT); intensive care; bibliometric analysis

Submitted Feb 25, 2021. Accepted for publication Jun 03, 2021.

doi: 10.21037/apm-21-895

View this article at: http://dx.doi.org/10.21037/apm-21-895 


\section{Introduction}

In clinical practice, critically ill patients can be roughly divided into two categories: infectious patients and noninfectious patients. The former includes primary severely infected patients, severely ill patients whose condition is aggravated by infection, and severely ill patients with secondary infections. Infection diagnosis and condition monitoring are important in critical care medicine, especially differential diagnosis and treatment effect monitoring of infected patients. Previously, the indicators commonly used for the diagnosis of infection in critically ill patients included white blood cells, C-reactive protein, and erythrocyte sedimentation rate. In recent years, procalcitonin (PCT) has been widely used in clinical practice, especially in the differential diagnosis of infection and disease monitoring (1-3). In non-infectious severe diseases, the value of PCT is controversial. Studies have found that for trauma patients, the initial peak level of PCT can well predict the risk of sepsis, multiple organ failure, and death (4). It can also predict the risk of acute kidney injury after brain trauma (5), but for patients with acute ST-segment elevation myocardial infarction, PCT cannot predict the risk of death during hospitalization after cardiogenic shock (6). Many guidelines currently recommend the use of PCT to guide clinical diagnosis and disease monitoring, however, some studies believe that the relevant evidence is still relatively weak, and further indepth research is needed (7). This study is based on the Science Citation Index Expanded (SCI-EXPANDED) database in the Web of Science Core Collection (WOSCC), and analyzes the relevant research literature on the application of PCT in patients in the intensive care unit in recent years. We aim to understand the current research status and provide suggestions for future research.

\section{Methods}

\section{Data resource}

The SCI-EXPANDED database in the WOSCC was used as the data source for searches.

\section{Search strategy}

The search subject terms (TOPIC) were as follows: step 1, use procalcitonin to search in Web of Science categories; step 2, search "Critical Care Medicine" in Web of Science categories; step 3, get the results from the intersection of
Table 1 Analysis of document types from the search results

\begin{tabular}{lcc}
\hline Literature type & Record & $\%$ of 1,243 \\
\hline Article & 665 & 53.50 \\
Meeting abstract & 297 & 23.89 \\
Editorial material & 93 & 7.48 \\
Letter & 93 & 7.48 \\
Review & 87 & 7.00 \\
Proceedings paper & 11 & 0.88 \\
Correction & 7 & 0.56 \\
Early access & 1 & 0.08 \\
News item & 1 & 0.08 \\
\hline
\end{tabular}

step 1 and 2; publication time: 1995 to now (latest update date: 2021-02-06); index: SCI-EXPANDED.

\section{Analysis}

The full record of the search results and the cited references were exported in text format, and CiteSpace software was used to analyze the annual publication status, subject distribution, country/institution distribution, journal distribution, author distribution, and keywords listed in the literature regarding critically ill patients.

\section{Statistical analysis}

This is a descriptive study. All data were expressed as number and percentage. No statistical comparison was conducted.

\section{Results}

\section{Characteristics of the literature}

There were a total of 1,243 research documents, including 665 articles, 87 review articles, 93 editorial materials, 93 letters, 297 conference abstracts, 11 conference documents, 7 revisions, 1 priority publication article, 1 news item article, and 1 annotation article (Tables 1,2; Figure 1). The citation frequency was 40,442 times, the h-index was 96 , and the average number of citations per item was 32.54 (Figure 2).

\section{The distribution of the research}

We used CiteSpace V software to generate a national 
Table 2 SCI annual distribution

\begin{tabular}{|c|c|c|}
\hline Year of publication & Record & $\%$ of 914 \\
\hline 2020 & 118 & 12.91 \\
\hline 2019 & 71 & 7.77 \\
\hline 2018 & 63 & 6.89 \\
\hline 2017 & 69 & 7.55 \\
\hline 2016 & 51 & 5.58 \\
\hline 2015 & 47 & 5.14 \\
\hline 2014 & 54 & 5.91 \\
\hline 2013 & 56 & 6.13 \\
\hline 2012 & 57 & 6.24 \\
\hline 2011 & 49 & 5.36 \\
\hline 2010 & 48 & 5.25 \\
\hline 2009 & 37 & 4.05 \\
\hline 2008 & 38 & 4.16 \\
\hline 2007 & 31 & 3.39 \\
\hline 2006 & 33 & 3.61 \\
\hline 2005 & 24 & 2.63 \\
\hline 2004 & 14 & 1.53 \\
\hline 2003 & 9 & 0.98 \\
\hline 2002 & 14 & 1.53 \\
\hline 2001 & 13 & 1.42 \\
\hline 2000 & 4 & 0.44 \\
\hline 1999 & 6 & 0.66 \\
\hline 1998 & 2 & 0.22 \\
\hline 1997 & 2 & 0.22 \\
\hline 1996 & 2 & 0.22 \\
\hline 1995 & 2 & 0.22 \\
\hline
\end{tabular}

$\mathrm{SCl}$, scientific citation index.

visualization map, as shown in Figure $3(\mathrm{~N}=120, \mathrm{E}=343$, $\mathrm{N}$ represents the number of network nodes, $\mathrm{E}$ represents the number of connections). The institutional visualization map is shown in Figure $4(\mathrm{~N}=1,000, \mathrm{E}=2,418)$. The results revealed that the top 5 countries with the highest volume of postings were the United States, Germany, France, Spain, and China. The top 5 centrally ranked countries were the United States, Italy, Spain, Germany, and France (Tables 3,4, Figure 3). The institutions with a large number of publications included Univ Basel Hosp, Univ Jena,
Univ Pittsburgh, and other university hospitals, while the organizations that had cooperated more extensively included Univ Basel Hosp, Univ Amsterdam, and Hannover Med Sch (Tables 5,6, Figure 4). There were 10 first authors who had published more than 10 papers, especially Schuetz and Mueller. Not only did they have a larger number of papers, their papers were also published in more authoritative journals, such as N Engl J M and Lancet, and their cooperation with other researchers and research institutions was also more extensive (Tables 7,8, Figure 5). In terms of reference citations, the research of authors such as Bone, Vincent, and Schuetz were cited more frequently, especially the citations of authors such as Meisner and Becker which were more concentrated (Tables 9,10, Figure 6). The above results show that countries such as the United States, Germany, France, and Spain are more advanced in this research field. In particular, research institutions such as Univ Basel Hosp have produced more results. Furthermore, the work of researchers such as Schuetz and Mueller is more influential.

\section{Distribution of journals}

There were a total of 1,243 PCT critical illness-related documents, involving 35 journals. Among them, there were 10 journals with more than 20 articles in Table 11, and a total of 665 journal articles accounting for $53.5 \%$ of the total literature (Table 11). The top 10 journals are listed in Table 8 by centrality and frequency of citations. It can be seen from Tables 11-13 that Critical Care Medicine, Intensive Care Medicine, and Critical Care were significantly higher than other journals in terms of the number of publications and the number of citations. Based on the above analysis results, it can be inferred that the journals including Critical Care Medicine, Intensive Care Medicine and Critical Care have great influence in this field.

\section{Keywords reflecting the research botspots and frontiers in this field}

With the help of CiteSpace V software, a keyword cooccurrence map was generated (Figure 7: $\mathrm{N}=729, \mathrm{E}=5,420$ ). The top 10 keywords by frequency and centrality are listed in Tables 14 and 15. It can be seen that PCT, sepsis, and infection were the focus of related research. We further used CiteSpace to detect bursts of keywords with high frequency, as shown in Figure 8. Combined with keyword references, hotspots gradually changed over time. In recent 


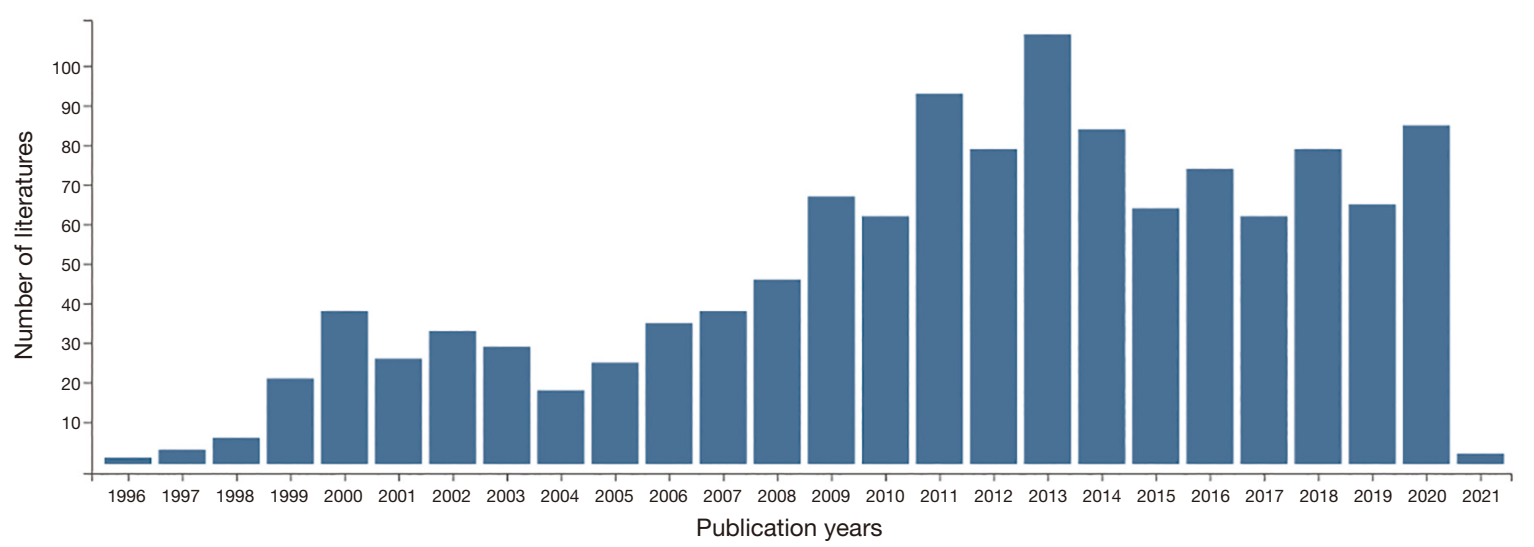

Figure 1 Annual publications.

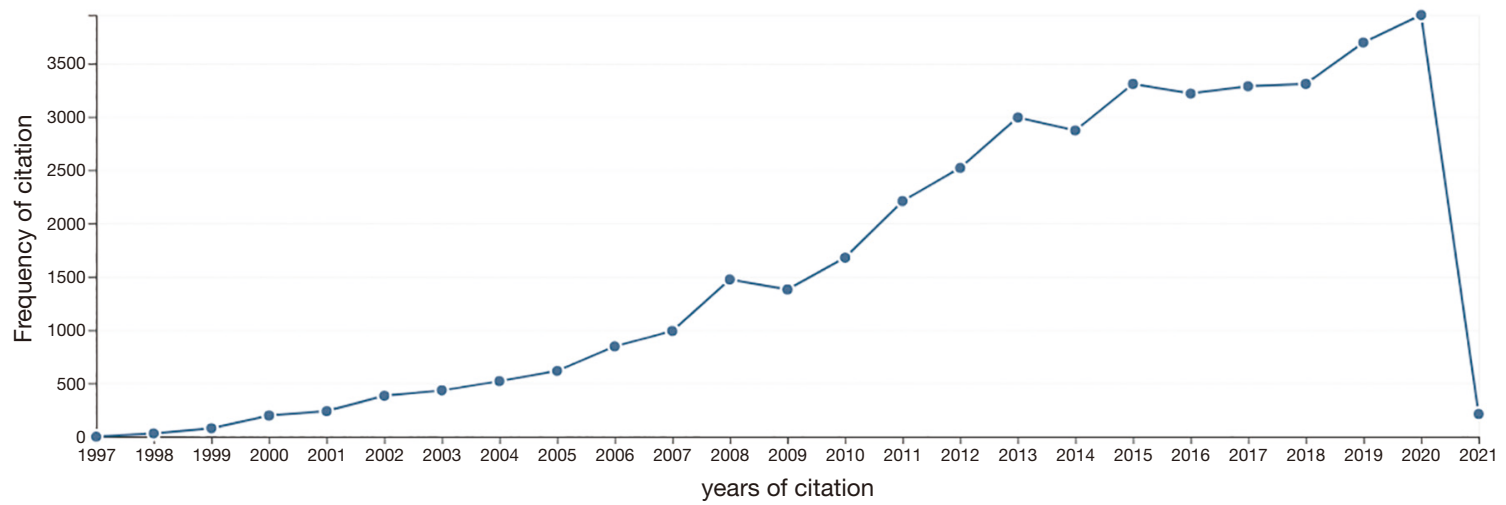

Figure 2 Annual citations.

years, hotspots included biomarkers, disease management, meta-analysis, and presepsin.

\section{Discussion}

PCT is a propeptide of calcitonin and a glycoprotein with hormonal activity. It consists of 116 amino acids and has a relative molecular weight of 13,000 . Human PCT is regulated by the calcitonin I gene on chromosome 11 . It is expressed in a variety of tissues, but the specific location is mainly affected by infection and pathogen types (8). In healthy people or when there is no bacterial infection, PCT is mainly synthesized by the neuroendocrine pathway, that is, the calcitonin I gene expressed by thyroid parafollicular cells and pulmonary neuroendocrine cells is regulated. At this time, the expression level is very low $(<0.1 \mathrm{pg} / \mathrm{L})$. Generally, it does not increase during viral infection. The main reason is that IFN $\gamma$ released by the human body can directly block the synthesis of PCT. When there is bacterial infection, various tissues outside the thyroid can be induced to express calcitonin I, leading to PCT being released into the blood in large quantities (9). The process is divided into 2 phases: the first is the early phase (2-3 h after infection), which is mainly caused by bacterial infection itself or endotoxin stimulation; and the latter is the delayed phase, which is mainly caused by inflammatory factors (such as TNF- $\alpha$, IL-1, IL-2, IL-6) which initiate a large amount of synthesis and release of PCT in various tissues outside the thyroid (10). The delayed phase is also an important reason for the peak of PCT within 12-24 h after systemic bacterial infection (11). The biological characteristics of PCT provide an important theoretical basis for the identification of infections and different pathogen infections, especially bacterial and viral infections (12). 


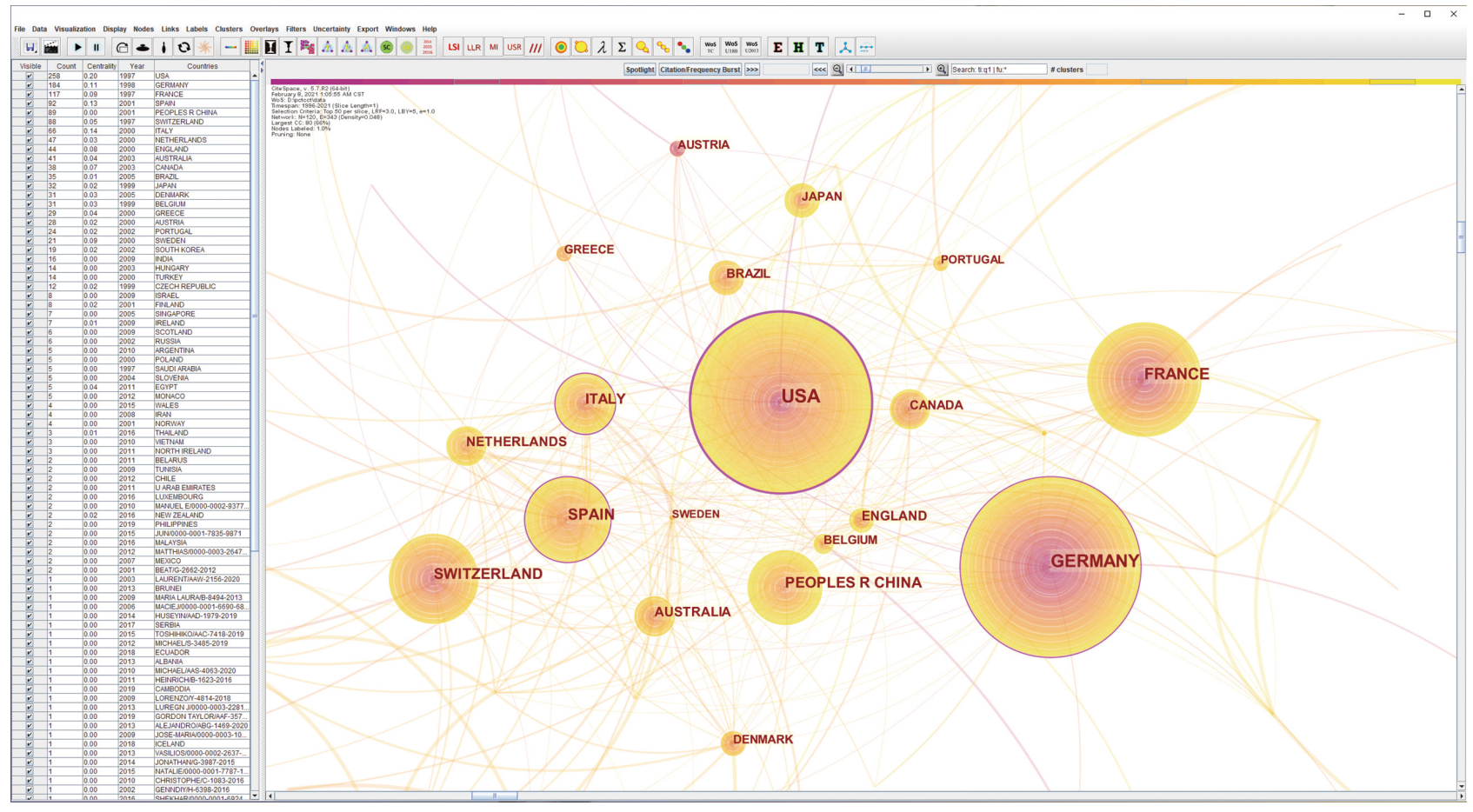

Figure 3 Country visualization map.

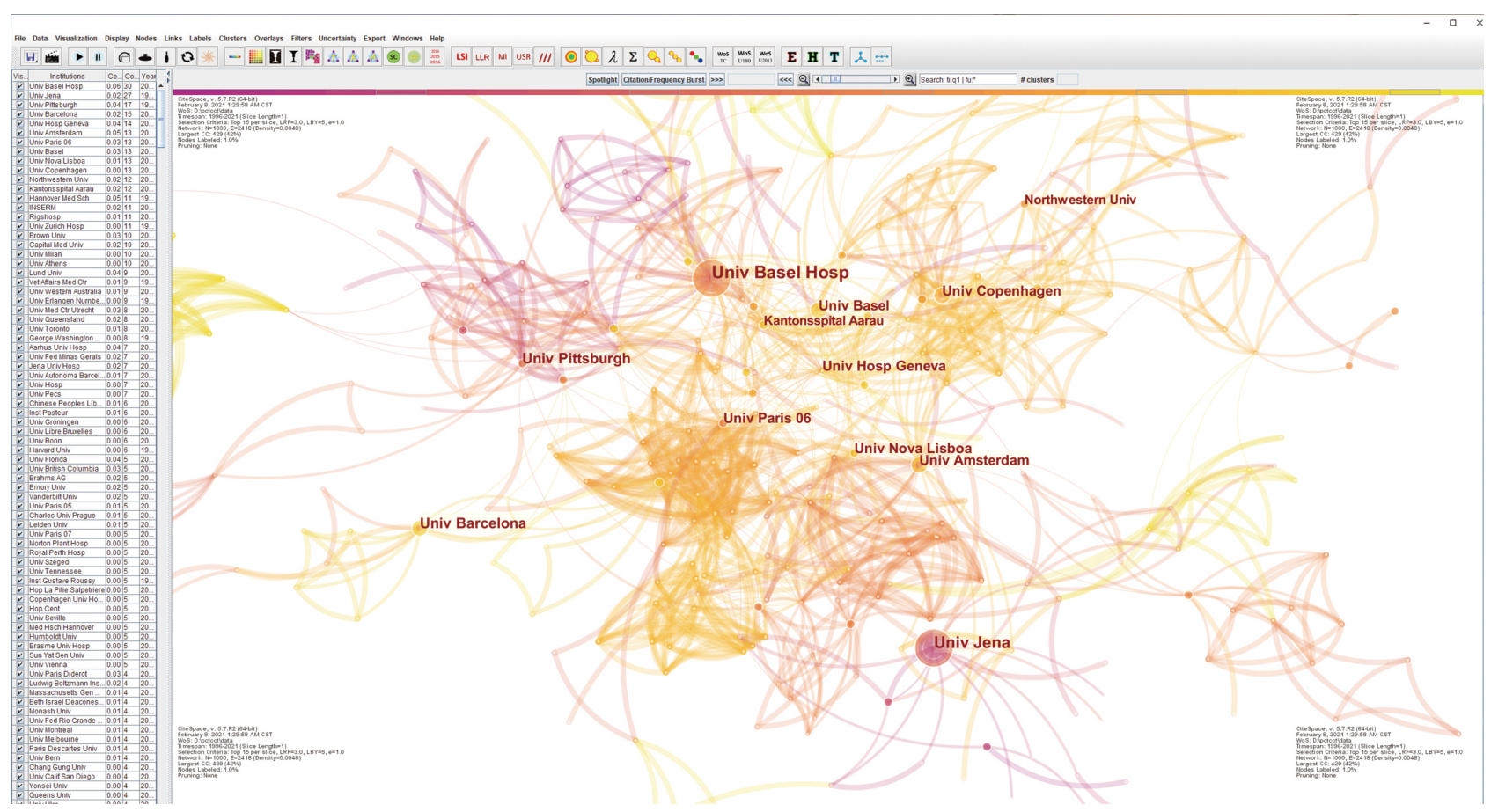

Figure 4 Institution visualization map. 
Table 3 Top 10 countries by publication frequency

\begin{tabular}{lcc}
\hline No. & Country & Frequency \\
\hline 1 & USA & 258 \\
2 & Germany & 184 \\
3 & France & 117 \\
4 & Spain & 92 \\
5 & China & 89 \\
6 & Switzerland & 88 \\
7 & Italy & 66 \\
8 & Netherlands & 47 \\
9 & England & 44 \\
10 & Australia & 41 \\
\hline
\end{tabular}

USA, United States of America.

Table 4 Top 10 countries by centrality

\begin{tabular}{lcc}
\hline No. & Country & Centrality \\
\hline 1 & USA & 0.2 \\
2 & Italy & 0.14 \\
3 & Spain & 0.13 \\
4 & Germany & 0.11 \\
5 & France & 0.09 \\
6 & Sweden & 0.09 \\
7 & England & 0.08 \\
8 & Canada & 0.07 \\
9 & Switzerland & 0.05 \\
10 & Australia & 0.04 \\
\hline
\end{tabular}

USA, United States of America.

Table 5 Top 10 institutions by publication

\begin{tabular}{lcc}
\hline No. & Institution & Frequency \\
\hline 1 & Univ Basel Hosp & 30 \\
2 & Univ Jena & 27 \\
3 & Univ Pittsburgh & 17 \\
4 & Univ Barcelona & 15 \\
5 & Univ Hosp Geneva & 14 \\
6 & Univ Paris 06 & 13 \\
7 & Univ Nova Lisboa & 13 \\
8 & Univ Basel & 13 \\
9 & Univ Amsterdam & 13 \\
10 & Univ Copenhagen & 13 \\
\hline
\end{tabular}

Table 6 Top 10 institutions by centrality

\begin{tabular}{lcc}
\hline No. & Institution & Centrality \\
\hline 1 & Univ Basel Hosp & 0.06 \\
2 & Univ Amsterdam & 0.05 \\
3 & Hannover Med Sch & 0.05 \\
4 & Univ Pittsburgh & 0.04 \\
5 & Univ Hosp Geneva & 0.04 \\
6 & Lund Univ & 0.04 \\
7 & Aarhus Univ Hosp & 0.04 \\
8 & Univ Florida & 0.04 \\
9 & Shanghai Jiao Tong Univ & 0.04 \\
10 & Univ Klinikum Aachen & 0.04 \\
\hline
\end{tabular}

Table 7 Top 10 authors by publication frequency

\begin{tabular}{lcc}
\hline No. & Authors & Frequency \\
\hline 1 & Schuetz P & 25 \\
2 & Mueller B & 23 \\
3 & Meisner M & 17 \\
4 & Reinhart K & 16 \\
5 & Christcrain M & 15 \\
6 & Povoa P & 14 \\
7 & Reinhart K & 14 \\
8 & Stolz D & 13 \\
9 & Tamm M & 12 \\
10 & Torres A & 11 \\
\hline
\end{tabular}

Table 8 Top 5 authors by centrality

\begin{tabular}{lcc}
\hline No. & Authors & Centrality \\
\hline 1 & Schuetz P & 0.01 \\
2 & Mueller B & 0.01 \\
3 & Nobre V & 0.01 \\
4 & Struck J & 0.01 \\
5 & Meierhellmann A & 0.01 \\
\hline
\end{tabular}




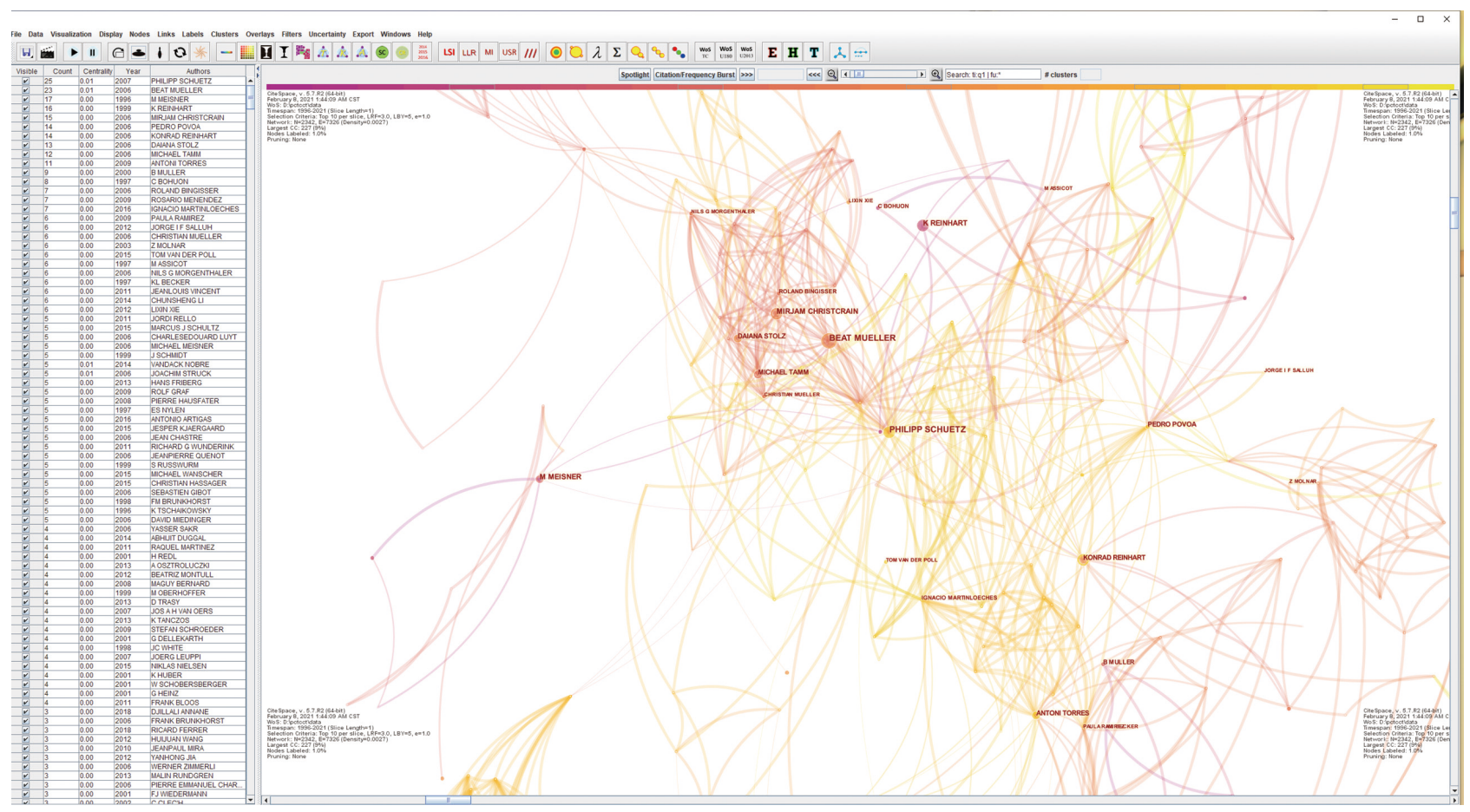

Figure 5 Visualization map of authors.

Table 9 Top 10 co-cited authors by frequency

\begin{tabular}{lcc}
\hline No. & Authors & Frequency \\
\hline 1 & Bone RC & 232 \\
2 & Vincent JL & 230 \\
3 & Schuetz P & 194 \\
4 & Christ-Crain M & 173 \\
5 & Meisner M & 134 \\
6 & Muller B & 110 \\
7 & Dellinger RP & 110 \\
8 & Assicot M & 106 \\
9 & Bouadma L & 104 \\
10 & Levy MM & 92 \\
\hline
\end{tabular}

In recent years, researchers have conducted a large number of studies in critically ill patients to observe the significance of PCT on the judgment of the severity of the disease, prognosis, and the use of antibiotics (13-15). The results found that PCT has a good reference value in emergency patients, critically ill patients, and in guiding the use of antibiotics. Many expert consensuses have been
Table 10 Top 10 co-cited authors by centrality

\begin{tabular}{lcc}
\hline No. & Authors & Centrality \\
\hline 1 & Meisner M & 0.46 \\
2 & Becker KL & 0.38 \\
3 & Burke DL & 0.33 \\
4 & Peter B & 0.33 \\
5 & Assicot M & 0.28 \\
6 & Davis TME & 0.19 \\
7 & Bone RC & 0.12 \\
8 & Christ-Crain M & 0.06 \\
9 & Vincent JL & 0.05 \\
10 & Kumar A & 0.05 \\
\hline
\end{tabular}

issued (16-19). However, these consensuses mainly focus on the guidance of PCT for the use of antibiotics. Regarding the significance of monitoring PCT in critically ill patients, some large-scale systematic reviews and meta-analyses have been published, further analyzing the application value of PCT from the perspective of evidence-based medicine (20-24). In this study, we found that the clinical application 


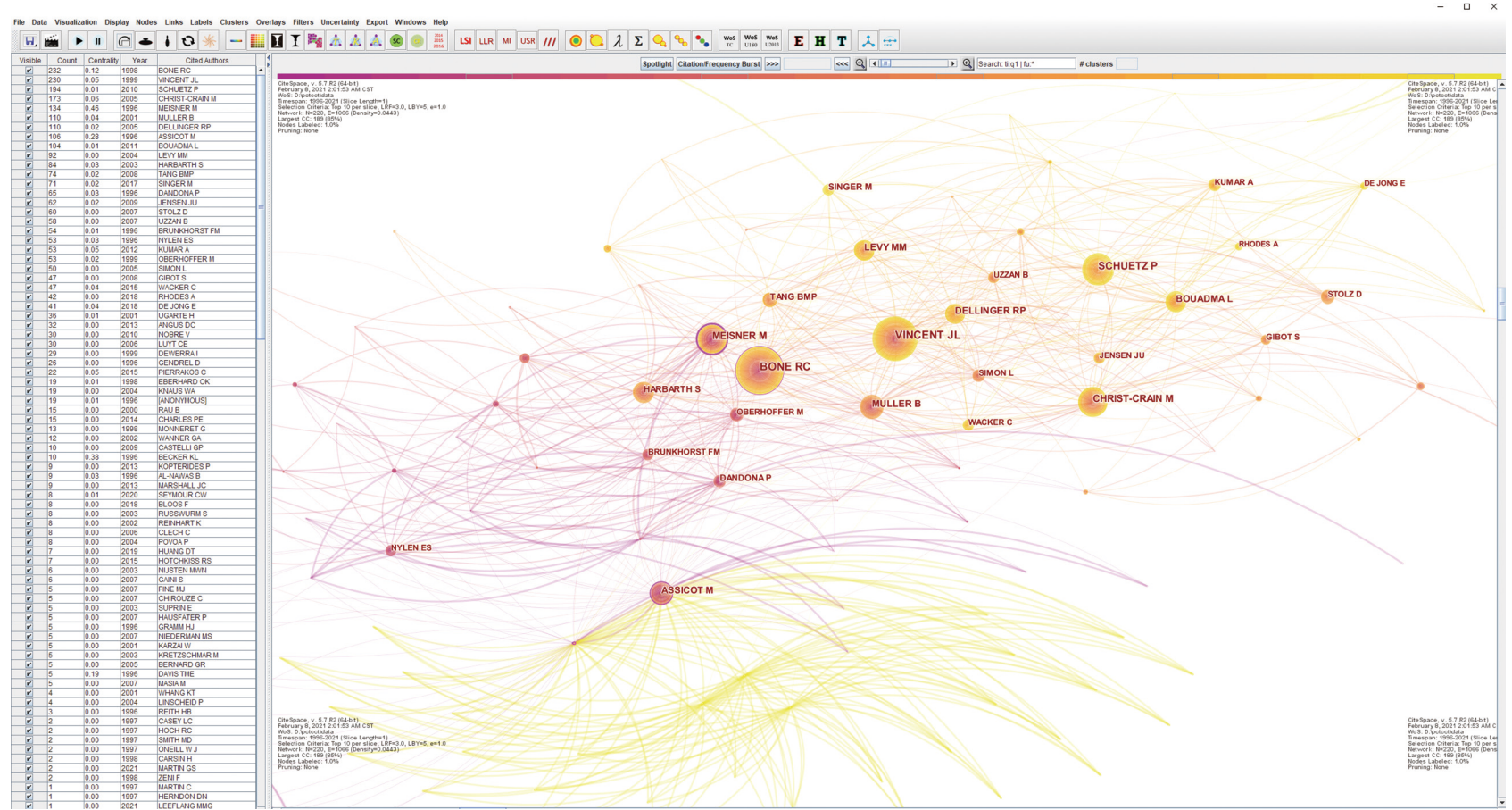

Figure 6 Visualization map of co-cited authors.

Table 11 Top 10 journals by publication

\begin{tabular}{llcc}
\hline No. & Journals & Record & \% of 1,243 \\
\hline 1 & Critical Care Medicine & 248 & 212 \\
2 & Intensive Care Medicine & 19.95 & 17.06 \\
3 & Critical Care & 189 & 15.21 \\
4 & American Journal of Respiratory and Critical Care Medicine & 95 & 7.64 \\
5 & Shock & 83 & 6.68 \\
6 & Chest & 82 & 6.60 \\
7 & Journal of Critical Care & 76 & 26 \\
8 & Burns & 26 & 2.11 \\
9 & Annals of Intensive Care & 25 & 2.09 \\
10 & Pediatric Critical Care Medicine & 2.01 & 1.69 \\
\hline
\end{tabular}

of PCT has gradually developed from the early diagnosis of bacterial infections to the current diagnosis of disease severity, prognostic indications, and guidance on the use of antibacterial drugs. Furthermore, related research is mainly concentrated in Europe and the United States. In several developed countries, such as the United States, Germany, and France, the institutions and researchers participating in the research are relatively concentrated. These results reflect that the application of PCT in the intensive care unit is becoming more extensive and in-depth, and the value of its clinical application is also increasing. On the other hand, it also reflects that there is a problem of geographical imbalance in related research, especially in developing regions such as Asia, Africa, and Latin America, which have conducted 
Table 12 Top 10 journals by citation

\begin{tabular}{lcc}
\hline No. & Journals & Frequency \\
\hline 1 & Crit Care Med & 823 \\
2 & Intens Care Med & 647 \\
3 & Crit Care & 579 \\
4 & Chest & 476 \\
5 & Am J Resp Crit Care & 474 \\
6 & Lancet & 438 \\
7 & New Engl J Med & 409 \\
8 & Jama-J Am Med Assoc & 402 \\
9 & Clin Infect Dis & 348 \\
10 & Shock & 250 \\
\hline
\end{tabular}

Table 13 Top 10 journals by centrality

\begin{tabular}{lcc}
\hline No. & Journals & Centrality \\
\hline 1 & Ann Intern Med & 0.21 \\
2 & Am J Med & 0.18 \\
3 & Shock & 0.09 \\
4 & Anesthesiology & 0.09 \\
5 & Arch Intern Med & 0.08 \\
6 & Arch Surg-Chicago & 0.08 \\
7 & J Infect Dis & 0.07 \\
8 & Blood & 0.07 \\
9 & Acta Endocrinol-Cop & 0.07 \\
10 & Burns & 0.06 \\
\hline
\end{tabular}

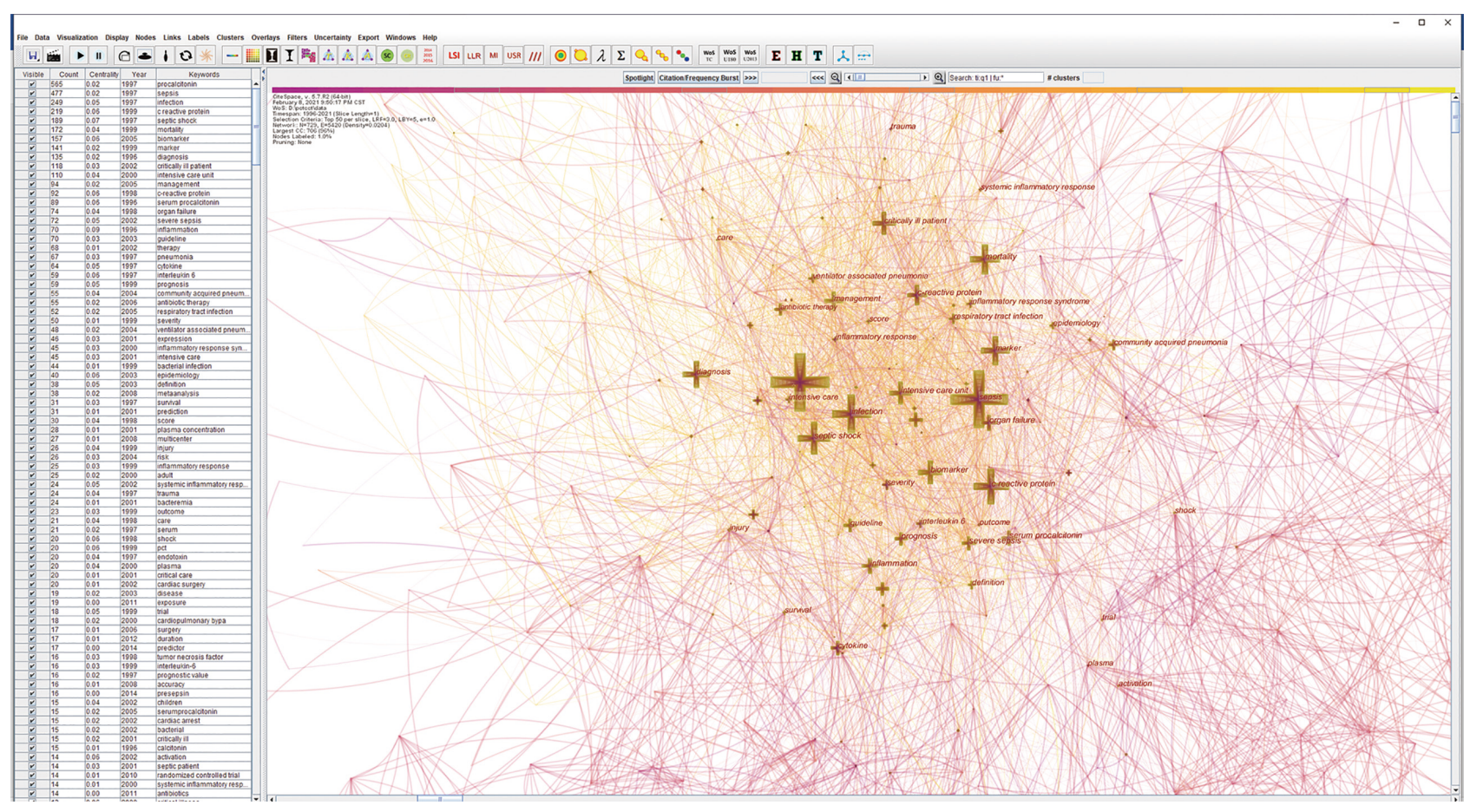

Figure 7 Keyword visualization map generated by CiteSpace V software.

fewer studies. The economic cost of PCT testing is not high, and the medical level of some developing countries around the world is relatively low, and making full use of PCT to guide severe cases, especially the diagnosis and treatment of infected patients, has a good cost-benefit ratio $(25,26)$.

Through our analysis, we also found that not only the countries and regions participating in the research were relatively concentrated, but also the research institutions and researchers were relatively concentrated, and the centrality value was not very high. That is to say, although there was a certain concentration, it was widely international. International cooperation, inter-agency cooperation, and inter-author cooperation are still insufficient. Therefore, in future research, more cooperation between various levels 
Table 14 Top 10 keywords by frequency

\begin{tabular}{lcc}
\hline No. & Keywords & Frequency \\
\hline 1 & Procalcitonin & 565 \\
2 & Sepsis & 477 \\
3 & Infection & 249 \\
4 & C-reactive protein & 219 \\
5 & Septic shock & 189 \\
6 & Mortality & 172 \\
7 & Biomarker & 157 \\
8 & Marker & 141 \\
9 & Diagnosis & 135 \\
10 & Critically ill patient & 118 \\
\hline
\end{tabular}

PCT, procalcitonin.
Table 15 Top 10 keywords by centrality

\begin{tabular}{lcc}
\hline No. & Keywords & Centrality \\
\hline 1 & Inflammation & 0.09 \\
2 & Septic shock & 0.07 \\
3 & C-reactive protein & 0.06 \\
4 & Biomarker & 0.06 \\
5 & C-reactive protein & 0.06 \\
6 & Serum procalcitonin & 0.06 \\
7 & Interleukin 6 & 0.06 \\
8 & Epidemiology & 0.06 \\
9 & Shock & 0.06 \\
10 & PCT & 0.06 \\
\hline
\end{tabular}

PCT, procalcitonin.

Top 25 Keywords with the Strongest Citation Bursts

\begin{tabular}{|c|c|c|}
\hline Keywords & Year Strength Begin End & ength Begin End \\
\hline procalcitonin & 1996 & 7.1119962004 \\
\hline cytokine & 1996 & 7.4119972003 \\
\hline serum & 1996 & 7.219972004 \\
\hline endotoxin & 1996 & 5.719972001 \\
\hline peritoniti & 1996 & $6.6319982002=$ \\
\hline tumor necrosis factor & 1996 & 5.7719982005 \\
\hline interleukin-6 & 1996 & 5.4819992002 \\
\hline plasma concentration & 1996 & 6.5920012009 \\
\hline expression & 1996 & 5.5420032009 \\
\hline organ failure & 1996 & 5.4120062009 \\
\hline community acquired pneumonia & 1996 & 8.0520072013 \\
\hline systemic inflammatory response & 1996 & 6.1720072010 \\
\hline respiratory tract infection & 1996 & 8.620092012 \\
\hline ventilator associated pneumonia & 1996 & 6.720102011 \\
\hline randomized controlled trial & 1996 & 6.1820102012 \\
\hline critically ill patient & 1996 & $5.8120102011=$ \\
\hline antibiotic therapy & 1996 & 8.5920112014 \\
\hline pneumonia & 1996 & 5.0320112014 \\
\hline biomarker & 1996 & 13.320132021 \\
\hline management & 1996 & 8.2820132021 \\
\hline predictor & 1996 & 7.3220142018 \\
\hline metaanalysis & 1996 & 5.9720142016 \\
\hline presepsin & 1996 & 5.0820142021 \\
\hline definition & 1996 & 5.6820152021 \\
\hline international consensus definition & 1996 & 4.9920172021 \\
\hline
\end{tabular}

Figure 8 Burst test of keywords by CiteSpace.

should be carried out to obtain more valuable evidencebased medical research. In terms of research hotspots, due to the inherent biological characteristics of PCT, it was mainly limited to the clinical application of infected and critically ill patients, thereby limiting the research field to these patients. However, the future research directions can continue on the basis of the current work. In-depth discussion can also be further analyzed in terms of judging 
the early and long-term prognosis of patients.

In summary, PCT has been widely used in critically ill patients, and more and more clinical studies support the use of PCT in the judgment of patients' conditions and to guide the use of antibacterial drugs, but there are also certain controversies. In the future, more multi-center in-depth studies are needed to further provide evidence-based medical research. This study had some shortcomings. This study did not compare the research status of other similar biomarkers horizontally, and there was also a lack of literature analysis on the combined use of PCT and other biomarkers. Increasingly, as more methods currently integrate multiple indicators for diagnosis, risk stratification, and prognostic judgment $(22,27)$, future research should continue to analyze the value of PCT and other biomarkers in comparison and with combined use. And this research is limited to literature analysis, and it may be more meaningful to add some clinical research results which is the future direction.

\section{Acknowledgments}

Funding: None.

\section{Footnote}

Conflicts of Interest: All authors have completed the ICMJE uniform disclosure form (available at https://dx.doi. org/10.21037/apm-21-895). The authors have no conflicts of interest to declare.

Ethical Statement: The authors are accountable for all aspects of the work in ensuring that questions related to the accuracy or integrity of any part of the work are appropriately investigated and resolved.

Open Access Statement: This is an Open Access article distributed in accordance with the Creative Commons Attribution-NonCommercial-NoDerivs 4.0 International License (CC BY-NC-ND 4.0), which permits the noncommercial replication and distribution of the article with the strict proviso that no changes or edits are made and the original work is properly cited (including links to both the formal publication through the relevant DOI and the license). See: https://creativecommons.org/licenses/by-nc-nd/4.0/.

\section{References}

1. Choi JJ, McCarthy MW. Novel applications for serum procalcitonin testing in clinical practice. Expert Rev Mol Diagn 2018;18:27-34.

2. Montassier E, Javaudin F, Moustafa F, et al. GuidelineBased Clinical Assessment Versus Procalcitonin-Guided Antibiotic Use in Pneumonia: A Pragmatic Randomized Trial. Ann Emerg Med 2019;74:580-91.

3. Huang DT, Yealy DM, Filbin MR, et al. ProcalcitoninGuided Use of Antibiotics for Lower Respiratory Tract Infection. N Engl J Med 2018;379:236-49.

4. AlRawahi AN, AlHinai FA, Doig CJ, et al. The prognostic value of serum procalcitonin measurements in critically injured patients: a systematic review. Crit Care 2019;23:390.

5. Wang R, He M, Ou XF, et al. Serum Procalcitonin Level Predicts Acute Kidney Injury After Traumatic Brain Injury. World Neurosurg 2020;141:e112-e117.

6. Sharma YP, Kasinadhuni G, Santosh K, et al. Prognostic role of procalcitonin in ST-elevation myocardial infarction complicated by cardiogenic shock. Asian Cardiovasc Thorac Ann 2021;14:218492320987918.

7. Tujula B, Hämäläinen S, Kokki H, et al. Review of clinical practice guidelines on the use of procalcitonin in infections. Infect Dis (Lond) 2020;52:227-34.

8. Branche A, Neeser O, Mueller B, et al. Procalcitonin to guide antibiotic decision making. Curr Opin Infect Dis 2019;32:130-5.

9. Wussler D, Kozhuharov N, Tavares Oliveira M, et al. Clinical Utility of Procalcitonin in the Diagnosis of Pneumonia. Clin Chem 2019;65:1532-42.

10. Paudel R, Dogra P, Montgomery-Yates AA, et al. Procalcitonin: A promising tool or just another overhyped test? Int J Med Sci 2020;17:332-7.

11. de Jong E, van Oers JA, Beishuizen A, et al. Efficacy and safety of procalcitonin guidance in reducing the duration of antibiotic treatment in critically ill patients: a randomised, controlled, open-label trial. Lancet Infect Dis 2016;16:819-27.

12. van der Does Y, Limper M, Jie KE, et al. Procalcitoninguided antibiotic therapy in patients with fever in a general emergency department population: a multicentre noninferiority randomized clinical trial (HiTEMP study). Clin Microbiol Infect 2018;24:1282-9.

13. Pepper DJ, Sun J, Rhee C, et al. Procalcitonin-Guided Antibiotic Discontinuation and Mortality in Critically Ill Adults: A Systematic Review and Meta-analysis. Chest 2019;155:1109-18.

14. Marik PE. Procalcitonin is an essential biomarker for hydrocortisone, ascorbic acid, and thiamine (HAT) therapy 
in patients with sepsis. Crit Care 2019;23:151.

15. Westwood M, Ramaekers B, Whiting P, et al. Procalcitonin testing to guide antibiotic therapy for the treatment of sepsis in intensive care settings and for suspected bacterial infection in emergency department settings: a systematic review and cost-effectiveness analysis. Health Technol Assess 2015;19:v-xxv, 1-236.

16. Schuetz P, Beishuizen A, Broyles M, et al. Procalcitonin (PCT)-guided antibiotic stewardship: an international experts consensus on optimized clinical use. Clin Chem Lab Med 2019;57:1308-18.

17. Bartoletti M, Antonelli M, Bruno Blasi FA, et al. Procalcitonin-guided antibiotic therapy: an expert consensus. Clin Chem Lab Med 2018;56:1223-9.

18. Special Committee of Hospital Infection Management and Control, the Society of Pediatrics, Chinese Medical Association. Expert consensus on clinical application of serum procalcitonin in pediatric infectious disease. Zhonghua Er Ke Za Zhi 2019;57:9-15.

19. Schuetz P, Bolliger R, Merker M, et al. Procalcitoninguided antibiotic therapy algorithms for different types of acute respiratory infections based on previous trials. Expert Rev Anti Infect Ther 2018;16:555-64.

20. Prkno A, Wacker C, Brunkhorst FM, et al. Procalcitoninguided therapy in intensive care unit patients with severe sepsis and septic shock--a systematic review and metaanalysis. Crit Care 2013;17:R291.

21. Wacker C, Prkno A, Brunkhorst FM, et al. Procalcitonin as a diagnostic marker for sepsis: a systematic review and

Cite this article as: Tan Y, Yu Q, Ma L, Chang J, Zhan X, Cui H, Liu Y, Sui Y. A bibliometric analysis of the application of procalcitonin in patients in the intensive care unit. Ann Palliat Med 2021;10(6):6367-6378. doi: 10.21037/apm-21-895 meta-analysis. Lancet Infect Dis 2013;13:426-35.

22. Ruan L, Chen GY, Liu Z, et al. The combination of procalcitonin and C-reactive protein or presepsin alone improves the accuracy of diagnosis of neonatal sepsis: a meta-analysis and systematic review. Crit Care 2018;22:316.

23. Tan M, Lu Y, Jiang H, et al. The diagnostic accuracy of procalcitonin and C-reactive protein for sepsis: A systematic review and meta-analysis. J Cell Biochem 2019;120:5852-9.

24. Wu CC, Lan HM, Han ST, et al. Comparison of diagnostic accuracy in sepsis between presepsin, procalcitonin, and C-reactive protein: a systematic review and meta-analysis. Ann Intensive Care 2017;7:91.

25. Voermans AM, Mewes JC, Broyles MR, et al. CostEffectiveness Analysis of a Procalcitonin-Guided Decision Algorithm for Antibiotic Stewardship Using Real-World U.S. Hospital Data. OMICS 2019;23:508-15.

26. Kip MMA, van Oers JA, Shajiei A, et al. Cost-effectiveness of procalcitonin testing to guide antibiotic treatment duration in critically ill patients: results from a randomised controlled multicentre trial in the Netherlands. Crit Care 2018;22:293.

27. Yu R, Zhou Q, Jiang S, et al. Combination of 16 S rRNA and procalcitonin in diagnosis of neonatal clinically suspected sepsis. J Int Med Res 2020;48:300060519892418.

(English Language Editor: C. Betlazar-Maseh) 